\title{
ANALISIS KEBUTUHAN MATERI PEMBELAJARAN KARYA ILMIAH BERBAHASA PRANCIS
}

\author{
Herman \\ Universitas Negeri Yogyakarta \\ Email: herman@uny.ac.id
}

\begin{abstract}
(Title: Needs Analysis of Learning Materials For French Academic Writing). This study aims to describe the needs of material for French academic writing courses. It shows $66.70 \%$ of respondents need to learn specific grammar to increase its effectiveness; $54.20 \%$ of respondents need special learning about essential terms for linguistic, literary or language teaching; $79.20 \%$ think that specialised terminology is needed to write research background. $54.20 \%$ thought that writing practice was very necessary, while $70.80 \%$ hoped there would be reading cativity for some scientific articles. $53.40 \%$ of respondents consider it necessary to master the logical connector of French. In addition, $50 \%$ of respondents think that a French scientific writing course is required and $25 \%$ want this to be mandatory. $62.50 \%$ expect this course to have at least 3 credits: 1 credit for writing theory and 2 credits for writing practice.
\end{abstract}

Keywords: need assessment, French academic writing

\section{PENDAHULUAN}

Mahasiswa Jurusan Pendidikan Bahasa Prancis FBS UNY diharuskan menulis resume sebanyak minimal 10 halaman dari karya ilmiah (skripsi) yang disusun, ketika akan mengajukan ujian tugas akhir skripsinya. Kewajiban ini telah dimulai beberapa tahun yang lalu dalam rangka meningkatkan kemampuan menulis para mahasiswa, terutama untuk penulisan karya ilmiah dalam bahasa Prancis. Hal ini juga sejalan dengan program Universitas Negeri Yogyakarta yang menggalakan pengunggahan karya ilmiah ke situs internet, yang memungkinkan dirujuknya (dalam wujud sitasi) karya tersebut oleh kalangan yang lebih luas dari civitas Akademika UNY sendiri. Karya ilmiah apapun yang ditulis dalam bahasa asing akan memberikan efek yang sangat luas bagi kemajuan pendidikan bahasa asing khususnya bahasa Prancis. Dapat dikatakan bahwa kegiatan penulisan resume skripsi dalam bahasa Prancis ini akan memberikan dampak positif kepada UNY untuk lebih dikenal oleh masyarakat pengguna bahasa Prancis (masyarakat frankofon) di berbagai belahan dunia. Untuk hal tersebut, teknologi informasi dan telekomunikasi dewasa ini memungkinkannya hampir tidak berbatas jarak maupun waktu. Artikel ilmiah berbahasa asing akan dapat diakses/dibaca siapapun.

Jurusan Pendidikan bahasa Prancis memiliki peluang yang besar dalam mengembangkan potensi pengunggahan artikel berbahasa Prancis. Setidaknya terdapat 40-50 mahasiswa dari jurusan ini yang menyelesaikan Tugas akhirnya setiap tahun dan membuat resume skripsi dalam bentuk artikel. Itu artinya terdapat 40-50 artikel yang beredar di dunia maya yang dapat diakses atau disitasi oleh pembaca frankofon. Jumlah ini akan memberikan makna yang cukup signfikan karena variasi bidang penelitian mahasiswa yang terdiri dari bidang pendidikan bahasa (linguistik terapan), bidang linguistik deskriptif dan bidang sastra yang diminati kalangan mahasiswa. Namun demikian kemampuan mahasiswa menulis menjadi perlu untuk diperhatikan. Terdapat kendala-kendala yang ditemukan dalam penerapan kebijakan ini yang dapat dikelompokkan menjadi 2 jenis: (1) resume skripsi dalam bahasa Prancis harus memenuhi azas-azas keilmiahan sebuah karya ilmiah sehingga dapat disejajarkan dengan makalah, artikel ilmiah dan tulisan ilmiah sejenis lainnya; (2) resume skripsi ini harus memenuhi berbagai kriteria kaidah kebahasaan dan kualitas konten yang berterima. 
Tampaknya Jurusan bahasa Prancis mengalami kewalahan menangani hal tersebut. Hanya terdapat satu mata kuliah 2 sks yakni Composition yang secara jelas mengarahkan mahasiswa untuk belajar menulis karya ilmiah. Beberapa mata kuliah menulis (Expression Ecrite) yang wajib ditempuh oleh mahasiswa selama 5 semester dengan masing-masing bobot 2 sks atau secara keseluruhan berjumlah 10 sks juga tidak secara pasti mengarahkan mahasiswa untuk memiliki kompetensi menulis karya ilmiah yang baik. Sementara itu buku ajar (ECHO) yang selama ini menopang pembelajaran keterampilan menulis kurang memberikan atau menyediakan secara khusus materi baik berupa konsep maupun contoh untuk kepentingan ini.

Oleh karena itu dapat dikatakan, keadaan ini menjadi tantangan berat bagi Jurusan Pendidikan Bahasa Prancis. Di satu sisi mahasiswa dituntut menguasai bahasa Prancis dengan dengan kemampuan yang baik atau setara level B2 CEFR (Common European Framework of Reference) yang mampu menulis karya ilmiah berbahasa Prancis. Di sisi lain, pembinaan penulisan resume berbahasa Prancis masih belum terprogram dalam kurikulum dan materi pembelajaran.

Mahasiswa yang hendak lulus sering meminta dosen pembimbing skripsinya untuk mengoreksi artikel yang dibuatnya. Tidak jarang atau bahkan sangat sering, tulisan yang dikonsultasikan tersebut merupakan draft yang belum diedit oleh mahasiswa. Bahkan beberapa tulisan hanya merupakan draft hasil terjemahan otomatis di internet seperti Google translate tanpa melalui proses editing yang memadai. Hal ini menunjukan adanya kelemahan dalam kemampuan mahasiswa menulis. Dosen pembimbing mengeluhkan beban kerja ini dan terpaksa meluangkan waktu yang banyak untuk membantu mahasiswa mengoreksi, menulis kalimat per kalimat atau bahkan mengoreksi secara keseluruhan teks yang telah dibuat oleh mahasiswa. Mahasiswa sendiri sering mengakui keberatan dengan tugas yang dibebankan kepada mereka ini, mengingat memang menulis karya ilmiah dalam bahasa Prancis atau bahasa asing bukanlah sebuah kebiasaan yang diajarkan sejak mereka pertama belajar di Jurusan Pendidikan bahasa Prancis FBS UNY. Terlebih lagi jika hal ini sampai menghambat kelulusan yang sudah di depan mata.

Persoalan ini tidak dapat dibiarkan menjadi lebih rumit dan berlarut bagi terselenggaranya proses pendidikan yang baik dan memperpanjang masa study mahasiswa yang pada gilirannya merugikan institusi secara keseluruhan. Untuk itu, diperlukan tindakan yang terencana dan sistematis yang memungkinkan diajarkannya materi penulisan karya ilmiah dalam bahasa Prancis, semacam Academic writing di Jurusan Pendidikan Bahasa Inggris, agar mahasiswa dapat menulis karyanya dengan baik dalam bahasa Prancis.

Penelitian ini merupakan sebuah tawaran solusi atas masalah tersebut di atas yang dimulai dari menganalisis kebutuhan pembelajar dan diteruskan dengan tindakan nyata. Tentu saja penelitian ini hanyalah awal dari sebuah road map yang harus diimplementasikan dalam kebijakan nyata terutama yang berhubungan dengan kurikulum, sylabi dan materi ajar untuk keterampilan menulis (Expression Ecrite).

\section{METODE}

Penelitian ini menerapkan analisis kebutuhan untuk mengetahui kebutuhan materi pembelajaran dan rencana pengembangan materi matakuliah Compostion. Analisis kebutuhan yang dimaksud merupakan kumpulan berbagai prosedur penarikan data untuk mengindentifikasi dan memvalidasi kebutuhan dan membuat urutan prioritas kebutuhan (Pratt,1990 dalam Brown, 1995:36). Untuk hal tersebut, digunakan kuesioner sebagai instrumen analisis kebutuhan yang dikembangkan dari kisi-kisi yang berisi indikator beberapa materi pembelajaran dalam wujud skala Likert, diantaranya digunakan kuesioner dan wawancara untuk mengetahui kebutuhan materi mata kuliah Composition secara umum dan kebutuhan materi gramatika dan materi terminologi khusus dalam keterampilan menulis ilmiah berbahasa Prancis. Selain menggunakan kuesioner, data diperoleh juga melalui wawancara kepada responden, yaitu 24 mahasiswa yang tengah mengerjakan skripsi. Penelitian dilak- 
sanakan di UNY selama satu bulan dengan melibatkan sampel mahasiswa semester lima dan tujuh yang diambil secara purposive sampling.

\section{HASIL DAN PEMBAHASAN Hasil}

Sebanyak 24 orang mahasiswa yang sedang menulis tugas akhir dan sedang menulis skripsi menjadi responden dalam penelitian ini. 24 responden tersebut terdiri dari sembilan mahasiswa $(37,5 \%)$ sedang menulis resume skripsi bidang linguistik, tujuh mahasiswa $(29,2 \%)$ menulis skripsi bidang pengajaran bahasa dan delapan mahasiswa $(33,3 \%)$ menulis skripsi bidang sastra. Berikut ini adalah distribusi data penelitian yang berhubungan dengan: (1) kebutuhan kosakata dan pengetahuan terminologi ilmu bahasa Prancis; (2) kebutuhan pengetahuan tatabahasa (Grammaire); (3) kebutuhan matakuliah menulis ilmiah (Composition).

Dalam artikel ini hanya akan dibicarakan kebutuhan yang terungkap dari data-data hasil rekapitulasi ketiga kelompok, tanpa membicarakan data satu per satu kelompok. Pertama data kebutuhan yang berhubungan dengan kosa kata (kebutuhan leksikal seperti kosakata dan terminologi). Kedua, data kebutuhan yang berhubungan dengan pengetahuan tata bahasa (Grammaire). Ketiga, data yang berhubungan dengan kebutuhan mata kuliah menulis ilmiah (Composition). Ketiga kelompok data tersebut disajikan dalam sebuah table dengan kolom-kolom vertikal berisis huruf A, B, C, D yang merupakan representasi opsi kriteria kebutuhan yang berbeda antara satu item dengan item lainnya. Di sini, huruf-huruf tersebut baru diketahui dalam pembahasan di bawah tabel.

\section{Pembahasan \\ Kebutuhan Pembelajaran Kosa Kata/Termi- nologi Penelitian}

Meskipun sebagian besar responden menyatakan bahwa mereka memiliki cukup banyak kosa kata untuk menulis sebuah resume, dalam beberapa salinan draf resume yang diteliti menunjukkan adanya kelemahan kemampuan menggunakan kosa kata dengan tepat atau kemampuan memilih kosa kata untuk sebuah maksud tertentu. Hal ini sejalan diduga akibat kurang dikuasainya ranah kosa kata bidang ilmu maupun kosa kata yang umum dipakai dalam sebuah tulisan ilmiah.

Dalam tabel 1. dibawah ini dapat dilihat sebanyak 16 dari $24(66,70 \%)$ responden menganggap bahwa mereka memiliki cukup kosa kata untuk menulis resume skripsi. 12 responden $(50 \%)$ di antaranya menganggap bahwa yang menjadi permasalahan bagi mereka justru pada tataran gramatika atau tata bahasa dibanding tataran kosa kata tersebut dalam menyusun sebuah kalimat atau paragraf.

Tabel 1. Data kebutuhan kosakata (leksik) bahasa Prancis

\begin{tabular}{lcccc}
\hline & A & B & C & D \\
\hline Kecukupan Kosakata & $12,50 \%$ & $66,70 \%$ & $20,80 \%$ & 0 \\
Ranah Kosakata & $25 \%$ & $50 \%$ & $20,80 \%$ & $4,20 \%$ \\
Kosakata dari buku ajar & $12,50 \%$ & $16,70 \%$ & $70,80 \%$ & 0 \\
Kosakata atau tata bhs & $8,30 \%$ & $16,70 \%$ & $20,80 \%$ & $54,20 \%$ \\
Cara menguasai Kosakata & $20,80 \%$ & $20,80 \%$ & $41,70 \%$ & $16,70 \%$ \\
\hline \multicolumn{5}{c}{$\mathbf{n = 2 4}$} \\
\hline
\end{tabular}

Tabel 2. Rekapitulasi data tentang kebutuhan terminologi khusus

\begin{tabular}{lcccc}
\hline & A & B & C & D \\
\hline Kebutuhan term.khusus & $50 \%$ & $41,70 \%$ & $8,30 \%$ & 0 \\
Kapan belajar term. khusus & $79,20 \%$ & $20,80 \%$ & 0 & 0 \\
Kebutuhan Term. Penulisan ilmiah & $25 \%$ & $66,70 \%$ & $8,30 \%$ & 0 \\
Matakuliah untuk terminologi & $66,70 \%$ & $25 \%$ & $8,30 \%$ & 0 \\
Keb. Latihan menulis essay etc. & $45,80 \%$ & $54,20 \%$ & 0 & 0 \\
\hline
\end{tabular}


Mahasiswa yang sedang menulis resume bidang penelitian linguistik, merasa tidak begitu menguasai kosa kata bidang linguistik. Demikian pula dengan yang sedang meneliti karya sastra, mereka merasa tidak menguasai kosa kata bidang ilmu sastra. Sedangkan mereka yang meneliti bidang pengajaran, mengaku tidak mengusai bidang statistik atau bidang metodologi penelitian. Sebagian besar responden memberikan pendapat bahwa buku ajar seperti Echo dan Campus tidak menyediakan kosa kata yang berhubungan dengan tugas penulisan resume mereka. Dengan kata lain, mereka tidak banyak mendapatkan kosa kata dari buku ajar yang mereka pelajari dari semester satu.

Penguasaan kosa kata sangat terkait dengan pengusaan terminologi khusus. Dalam tabel 2. dapat dilihat sebagian $(50 \%)$ responden menyatakan bahwa mereka membutuhkan terminologi khusus dalam bidang ilmu kebahasaan seperti linguistik, teori sastra atau pengajaran bahasa sesuai dengan bidang yang sedang mereka tulis. 79,20\% responden menghendaki agar penguasaan terminologi khusus ini dimiliki mahasiswa sebelum menulis skripsi atau ketika mereka mengikuti mata kuliah bidang ilmu masing-masing. Dapat dikatakan bahwa pemerolehan kosa kata atau terminologi bidang kajian linguistik, sastra dan pengajaran bahasa merupakan bagian yang sama pentingnya dengan pemerolehan pengetahuan tentang ilmu tersebut. Sebanyak $66,70 \%$ responden berpendapat bahwa terminologi bidang penelitian atau yang berhubungan dengan penguasaan bahasa selingkung yang sering atau biasa ditemukan dalam bidang penelitian dan penulisan karya ilmiah sangat penting untuk mereka. Terminologi itu diharapkan dapat ditemukan dalam mata kuliah Metodologi Penelitian sastra, linguistik maupun Metodologi Pengajaran Bahasa. Di sisi lain, responden berpendapat bahwa mata kuliah khusus untuk pemerolehan kosa kata atau terminologi khusus ini tidak perlu diadakan sendiri di luar mata kuliah yang sudah ada (composition). Para responden justru berharap dapat mengenal sebanyak mungkin ragam bahasa ilmiah dan terminologi pada mata kuliah Metodologi Penelitian. Dalam tabel 2 dapat dilihat meskipun sebagian responden $(54,2 \%)$ berpendapat bahwa latihan menulis ilmiah adalah sesuatu yang sangat penting, namun mereka tidak menginginkan sebuah matakuliah khusus untuk mempelajarinya. Dibutuhkan sebuah sinergi matakuliah yang dapat memenuhi kebutuhan para mahasiswa untuk mampu mengembangkan kalimat dengan kota kata maupun terminologi yang baik. Sementara $45,8 \%$ responden berpendapat bahwa dibutuhkan seorang dosen yang sesuai bidang ilmunya memberikan materi Composition agar terminologi ilmu dapat secara langsung dibicarakan saat berlatih menulis resume maupun karya ilmiah berbahasa Prancis.

\section{Kebutuhan Pembelajaran Tata Bahasa (Grammaire)}

Pengetahuan tatabahasa adalah salah satu dari beberapa gejala permasalahan yang ditemukan dalam sebagian besar draft resume yang diteliti. Beberapa faktor diasumsikan menjadi penyebabnya, di antaranya kurangnya penguasaan grammaire, interferensi bahasa pertama, kerumitan bahasa Prancis dan proses pemerolehan bahasa Prancis yang gagal. Sebagian besar responden menganggap sistem Kala dan Modus bahasa Prancis rumit (83\%). Jika dibandingkan dengan kesalahan yang terdapat dalam draf resume mahasiswa, pendapat ini cukup beralasan karena peneliti menemukan pemakaian Kala dan modus yang tidak tepat dalam kalimat meskipun bentuk yang diberikan sudah menunjukkan adanya penguasaan konjugasi yang cukup baik. Kemampuan menulis bentuk kalimat yang cukup baik sering tidak diikuti oleh kemampuan menggunakan dan memaknainya dengan baik dalam konteks yang tepat. Keinginan untuk kembali mempelajari secara khusus tatabahasa untuk penulisan resume ini dianggap sebagai hal perlu oleh $87,5 \%$ responden (jawaban A\&B). Ini menunjukkan adanya kebutuhan yang kuat untuk mempelajari kembali fungsi dan pemakaian yang benar dari penguasaan pengetahuan tatabahasa dasar yang sudah pernah dipelajari.

Dalam tabel 4 di bawah ini, dapat dilihat sebanyak $83,00 \%$ responden menganggap bahwa penguasaan gramatika yang kurang baik masih menjadi persoalan utama dalam penulisan resume. Persoalan gramatika yang 
Tabel 4. Rekapitulasi data kebutuhan materi tata bahasa Prancis dalam persentase

\begin{tabular}{lcccc}
\hline & A & B & C & D \\
\hline Penguasaan sistem kala dan modus & $4,20 \%$ & $83,00 \%$ & $8,30 \%$ & $4,20 \%$ \\
Grammaire khusus untuk karya ilmiah & $45,80 \%$ & $41,70 \%$ & $12,50 \%$ & - \\
Perlunya Konektor logis & $33,30 \%$ & $58,30 \%$ & $8,30 \%$ & - \\
Hal tentang konektor logis & $4,20 \%$ & - & $91,70 \%$ & $4,20 \%$ \\
Hal tentang Preposisi & $41,70 \%$ & $50 \%$ & $8,30 \%$ & - \\
Genre dan nombre & - & $8,30 \%$ & $79,20 \%$ & $12,50 \%$ \\
\hline
\end{tabular}

dimaksud adalah yang berhubungan dengan penggunaan Kala, Mode, dan Aspek. 45,8\% dan $41,7 \%$ responden masih menganggap sangat perlu dan mempertimbangkan untuk menambah materi pembelajaran gramatika untuk menunjang kemampuan mereka menulis. Sedangkan sebanyak 53,4\% atau 14 dari 24 responden menganggap materi Konektor Logis perlu dipelajari secara khusus. Hal ini juga ditunjukkan oleh $91,70 \%$ responden yang masih menganggap konektor logis sebagai sesuatu hal yang rumit, padahal dalam menulis hubungan logis, mahasiswa harus mampu menggunakan Konektor logis dengan baik.

Pemakaian preposisi yang tepat merupakan salah satu kesalahan yang sering dijumpai dalam draf resume mahasiswa. 50\% responden yang menganggap materi ini perlu dikuasai dan sebanyak $41,7 \%$ responden menganggap wajib mempelajari preposisi secara khusus untuk dapat menulis resume. Sebaliknya pemakaian pemarkah genre dan jamak belum dianggap oleh reponden sebagai sesuatu yang mendesak. Ini ditunjukkan oleh 79,2\% responden yang menganggap hal itu sebagai persoalan yang bisa diselesaikan dan dikuasai oleh mahasiswa sendiri.

Kesalahan lain yang sering dijumpai dalam draf resume mahasiswa adalah tidak munculnya atau kesalahan pemakaian konektor logis yang menyebabkan adanya kesalahan berlogika atau kurang argumentatifnya sebuah pernyataan. Namun demikian, sebagian responden $(58,30 \%)$ mengakui bahwa pemakaian konektor logis ini sebagai hal yang perlu dikuasai bahkan 33,30\% manyatakan hal ini wajib dipelajari secara khusus. Hal ini menunjukkan kurangnya penguasaan dibandingkan dengan tingginya kebutuhan mereka akan penguasaan materi ini. Hal ini diperkuat dengan sikap responden terhadap pemakaian konektor logis dalam penulisan resume yang menunjukkan kecenderungan positif dengan 91,70\%.

Preposisi atau kata depan merupakan faktor ketiga kesalahan penulisan resume. Tidak dipungkiri bahwa umumnya mahasiswa menyamaratakan pemakaian preposisi dalam bahasa Prancis dengan preposisi dalam bahasa Indonesia atau bahkan dalam bahasa Inggris yang pernah mereka kenal. Diasumsikan hal ini terjadi akibat adanya interferensi kedua bahasa di atas ketika mahasiswa menulis dalam bahasa Prancis. Banyaknya varian preposisi dalam bahasa Prancis dan kurangnya pengenalan terhadap pemakaian preposisi ini dianggap menjadi sumber kesalahan yang terjadi. Sehingga $50 \%$ menganggap hal ini perlu dipelajari dan $41,70 \%$ menganggap hal ini wajib dipelajari secara khusus.

Pemakaian pemarkah genre dan nombre (tunggal/jamak) merupakan faktor keempat kesalahan penulisan resume. Namun diasumsikan kesalahan ini bukan disebabkan oleh kurangnya pengetahuan mahasiswa tentang kedua hal tersebut melainkan oleh faktor kebiasaan. Pemakaian pemarkah genre bukanlah hal rumit demikian juga pemarkah jamak, tetapi kurangnya kebiasaan berpikir dalam bahasa Prancis membuat pengetahuan ini tidak secara otomatis bekerja dalam pikiran mahasiswa ketika menulis atau mengekspresikan pikirannya. Secara meyakinkan responden memilih menempatkan persoalan ini sebagai hal yang bisa mereka atasi sendiri karena dianggap bukan sebagai prioritas untuk dipecahkan. $12,50 \%$ menyatakan hal ini sudah dikuasai dan hanya $8,30 \%$ menyatakan hal ini memang bermasalah.

\section{Kebutuhan Matakuliah Composition}

Dalam tabel 5. di bawah ini dapat dilihat bahwa matakuliah Composition masih di- 
Tabel 5. Rekapitulasi data kebutuhan matakuliah Composition dalam persentase

\begin{tabular}{lcccc}
\hline & A & B & C & D \\
\hline MK khusus karya ilmiah & $25 \%$ & $50 \%$ & $20,80 \%$ & $4,20 \%$ \\
Jumlah sks dan komposisi T/P & $4,20 \%$ & $62,50 \%$ & $20,80 \%$ & $12,50 \%$ \\
Materi kuliah & $70,80 \%$ & $12,50 \%$ & $16,70 \%$ & - \\
Pengajar & $33,30 \%$ & $20,80 \%$ & $29,20 \%$ & $16,70 \%$ \\
\hline \multicolumn{5}{c}{$\mathbf{N = 2 4}$} \\
\hline
\end{tabular}

anggap relevan dan justru diharapkan memiliki kredit 3 sks. Sebanyak 70,8\% responden menginginkan mata kuliah Composition memiliki materi yang memperkenalkan kepada para mahasiswa berbagai tulisan karya ilmiah dan latihan menulisnya dengan komposisi $50 \%$ kegiatan membaca karya ilmiah berbahasa Prancis dan $50 \%$ kegiatan berisi latihan menulis karya ilmiah dalam bahasa Prancis.

Composition yang selama ini merupakan mata kuliah garda terakhir untuk mempersiapkan mahasiswa menulis karya ilmiah dalam bahasa Prancis memiliki posisi yang strategis. Mata kuliah ini menjadi titik balik bagi mahasiswa untuk mendayagunakan segenap pengetahuan dan pengalamannya belajat mengekspresikan pikiran dalam bahasa Prancis secara tertulis. Sehingga dapat dipahami jika terdapat $50 \%$ responden yang berpendapat bahwa matakuliah ini diperlukan bahkan 25\% menginginkan matakuliah ini diwajibkan.

Jika ditilik dari tujuan pembelajaran dan cakupan materinya, selama ini mata kuliah Composition dengan 2 sks tersebut difokuskan kepada keterampilan menulis dengan ekuivalensi standar B2 CECR. Hal ini memberikan konsekuensi yang perlu dicermati karena sebagian besar $(62,5 \%)$ mahasiswa berpendapat hal tersebut berat dan menginginkan agar jumlah sks nya ditambah dengan komposisi 1 sks teori dan 2 sks praktik dan 20,80\% lainnya menghendaki jika memang harus 2 sks agar matakuliah ini sepenuhnya berisi praktik menulis. Pengetahuan Kemampuan menulis saja dianggap tidak cukup bila tidak dibarengi dengan praktik menulis draf resume.

Di samping itu, dibutuhkan sebuah sistem pembelajaran matakuliah Composition yang adaptif dengan kebutuhan mahasiswa agar materi yang disajikan memiliki dayaguna ketika dibutuhkan. 70,80\% responden meng- hendaki aktivitas membaca karya ilmiah berbahasa Prancis disamping praktik menulis. Hal ini diasumsikan bahwa mahasiswa membutuhkan sebuah model tulisan yang sesuai dengan yang dibutuhkannya. Sementara untuk kebutuhan pengajar yang memberikan matakuliah ini, pendapat responden terpecah, secara hampir merata, yakni antara dosen metode penelitian yang diasumsikan mengenal baik terminologi dan peristilahan serta metode ilmiah dalam penulisan, kemudian dosen matakuliah keilmuan yang juga dianggap menguasai terminologi dan metode ilmunya serta dosen keterampilan menulis yang dianggap menguasai kaidah-kaidah penulisan.

\section{MK khusus karya ilmiah}

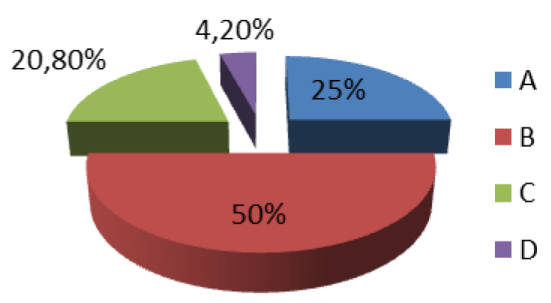

Sejumlah 50\% responden berpendapat bahwa perlu diadakan mata kuliah khusus untuk membekali mahasiswa menulis karya ilmiah/resume dalam bahasa Prancis. 25\% di antaranya berpendapat matakuliah ini sangat penting, 20,80\% menganggap perlu untuk dipertimbangkan dan $4,20 \%$ merasa hal ini belum perlu.

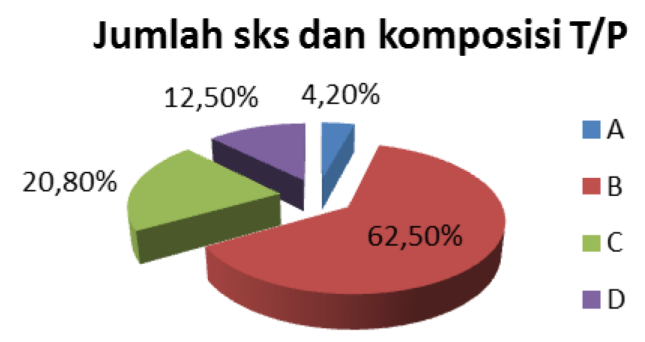


Sejumlah $62,50 \%$ responden berpendapat bahwa mata kuliah Composition sebaiknya memiliki 3 sks yang terdiri dari 1 sks teori dan 2 sks praktik. 20,8\% berpendapat cukup dengan 2 sks praktik. Sementara terdapat $12,5 \%$ yang berpendapat 2 sks praktik dan $4,2 \%$ yang berpendapat 4 sks (2T dan $2 \mathrm{P})$.

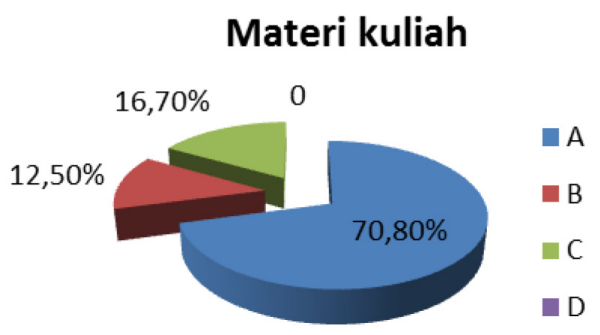

Sejumla $70,80 \%$ responden berpendapat bahwa separuh dari materi kuliah sebaiknya berisi kegiatan membaca karya ilmiah dan separuhnya lagi menulis karya ilmiah. 16,70\% berpendapat cukup berisi latihan menulis karya ilmiah saja dan $12,5 \%$ berpendapat matakuliah ini berisi pembelajaran kosa kata dan latihan tatabahasa untuik karya ilmiah.

\section{Pengajar}

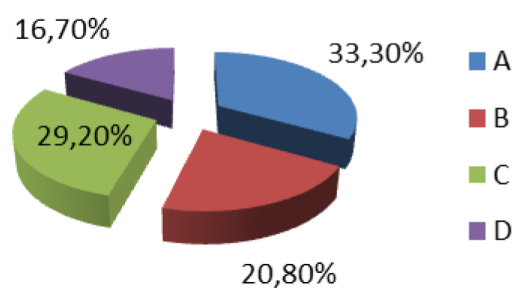

Sejumlah 33,30\% responden berpendapat bahwa pengajar matakuliah Composition sebaiknya dosen bidang ilmu linguistik, pengajaran bahasa atau sastra sesuai dengan bidang yang dikaji mahasiswa. Sementara $29,20 \%$ berpendapat pengajar matakuliah ini terdiri dari dosen matakuliah metodologi penelitian dan sorang dosen keterampilan menulis. 20,80\% berpendapat bahwa pengajar matakuliah ini terdiri dari dari dosen matakuliah bidang ilmu dan seorang dosen keterampilan menulis. 16,70\% berpendapat bahwa pengajar matakuliah ini terdiri dari dosen matakuliah metodologi penelitian dan seorang dosen bidang ilmu.

\section{SIMPULAN}

Beberapa kesimpulan dan sekaligus saran dapat diajukan berkenaan dengan hasil penelitian ini, di antaranya adalah sebagai berikut.

Pertama, sebagian besar responden menganggap bahwa mereka memiliki cukup kosa kata untuk menulis resume skripsi. Meskipun demikian, dalam beberapa salinan draf resume yang diteliti menunjukkan adanya kelemahan kemampuan menggunakan kosa kata dengan tepat atau kemampuan memilih kosa kata untuk sebuah maksud tertentu. Hal ini diduga akibat kurang dikuasainya ranah kosa kata bidang ilmu maupun kosa kata yang umum dipakai dalam sebuah tulisan ilmiah.

Kedua, terminologi bidang penelitian atau yang berhubungan dengan penguasaan bahasa selingkung yang sering atau biasa ditemukan dalam bidang penelitian dan penulisan karya ilmiah sangat penting dikuasai. Terminologi itu diharapkan dapat ditemukan dalam mata kuliah Metodologi Penelitian sastra, linguistik maupun Metodologi Pengajaran Bahasa.

Ketiga, sebagian responden berharap dapat mengenal sebanyak mungkin ragam bahasa ilmiah dan terminologi pada mata kuliah Metodologi Penelitian. Dan sebagian responden lagi berpendapat bahwa matakuliah Composition yang telah ada sekarang masih dianggap relevan dan justru diharapkan memiliki kredit 3 sks dengan materi yang memperkenalkan kepada berbagai varian tulisan karya ilmiah dan latihan menulisnya.

Keempat, sebagian responden menganggap bahwa materi tata bahasa yang perlu dikuasai adalah yang berhubungan dengan penggunaan Kala dan Mode untuk penulisan ilmiah, serta pengetahuan tentang Konektor Logis yang perlu dipelajari secara khusus, karena dianggap sebagai sesuatu hal perlu dalam pengungkapan fakta atau pikiran logis, agar mahasiswa harus mampu menggunakan Konektor logis ini dengan baik.

\section{DAFTAR PUSTAKA}

Bailey, S. (2003). Academic Writing A Handbook for International Students (Second edition). London: Routledge 
Brown, J. D. (1995). The Elements of Language Curriculum: A Systematic Approach to Program Development Teaching Methods Series Newbury House Teacher Development: Heinle $\&$ Heinle

Brown, A. \& Dowling, P. (1998). Doing Research/Reading Research: A Mode of Interrogation for Education: The Falmer Press
Clark, J. L. (1987). Curriculum Renewal in School Foreign Language Learning, New York: Oxford University Press.

Conseil de l'Europe C.E. (2001). Un cadre européen commun de référence pour les langues: apprendre, enseigner, évaluer, Strasbourg: Unité des Politiques linguistiques

Henning, E., Sarah Gravett, S., Wilhelm van Rensburg. (2005). Finding your way in Academic Writing, (SECOND EDITION) Pretoria: Van Schaik Publishers 